\title{
Effect pH Adsorption of Naphtol Dye Using Humic Acid Adsorbent Result of Peat Isolation from Kalimantan
}

\author{
Masyithah Nisvi Prandini ${ }^{1, *}$, Maya Rahmayanti ${ }^{2}$ \\ ${ }^{1}$ Chemistry Study Program, Postgraduate Faculty, Sebelas Maret University, \\ J1. Ir. Sutami No.36A Kentingan Surakarta 57126, Telp. 0271-646994 \\ ${ }^{2}$ Chemistry Departement, Faculty of Science and Technology, UIN Sunan Kalijaga \\ J1. Marsda Adisucipto No 1 Yogyakarta 55281, Indonesia. Tel. +62-274-540971, Fax. +62-274-519739. \\ Email*: nisviprandini@gmail.com
}

\begin{abstract}
Adsorption of naphtol dye has been done by using humic acid adsorbent taken from Kalimantan peat isolation. This study aims to determine the effect of $\mathrm{pH}$ adsorption on naphtol dyes with humic acid taken from Kalimantan peat isolation. Humic acid which is using as an adsorbent to adsorb the naphthol dye solution. The adsorption process was measured using a UV-Vis spectrophotometer to determine the concentration of the adsorbed naphthol dye. The adsorption study from the research results showed that the adsorption of naphtol coloring to humic acid was optimal at $\mathrm{pH} 2$.
\end{abstract}

Keywords: Adsorption, humic acid, naphtol dye, isolation

\section{INTRODUCTION}

Indonesia is a developing country which is currently carrying out development in the industrial field. One of the fast growing industrial developments is the batik textile industry. Batik is one of Indonesia's distinctive craftsmanship. Cities that make batik as a mainstay commodity include Pekalongan, Surakarta and Yogyakarta. As we already know that the batik industry has been growing and developing since decades ago.

Batik industry is now demanded to continue to improve and improve its work standards. Small and medium batik industries are able to do and implement it, so that it can indirectly cause problems for the environment around the batik industry. Environmental problems related to textile industry activities are mostly caused by the use of organic and inorganic dyes which are difficult to dissolve in water. Some of these organic compounds are difficult to decipher and are carcinogens. Water discoloration due to batik dye waste is still a big problem for the environment. This is because the dye is difficult to be decomposed naturally by the receiving water body.

Synthesis coloring substances (chemicals) which are disposed of carelessly without processing will cause environmental pollution. The liquid waste can cause damage to the river ecosystem so that the fish and living things in the river die. The river water also cannot be used anymore, especially if the water is polluted until it permeates and pollutes well water. Sunu (2001) states that almost all chemical dyes are toxic and if they enter the human body will stimulate cancer growth.

Disposing of colored wastewater as done by the batik industry can poison the aquatic biota in these waters. The intense color will prevent sunlight from penetrating into the body of water.

This can affect the process of photosynthesis in water which results in the lack of oxygen produced in the process of photosynthesis (Setyaningsih, 2007).

The dyes most widely used by the batik industry in the city of Yogyakarta are naphtol and indigol dyes. Naphtol colorant is a compound that does not dissolve in water consists of two basic components, namely the AS naphtol group (Anilid Acid) and the color generating component, namely the diazonium group or commonly called salt, if it is combined into a colored compound if it has been dissolved (Laksono, 2012).

Adsorption is one method developed to remove pollutants (Rachmawati, 2016). The adsorption method can reduce the levels of metals in liquid waste by absorbing these metals into the surface of the adsorbent (Putra et al., 2014). Adsorption methods are generally based on the interaction of functional groups such as $\mathrm{OH},-\mathrm{NH},-\mathrm{SH}$ and $-\mathrm{COOH}$ (Rahmawati and Sri, 2012).

In principle, dyes can interact with components from the soil or sediment, especially minerals and refractory organic materials. This level of interaction is a key factor in controlling the mobility of dyes found in the environment. According to Benerjee et al., (1973) and Ohga et al., (1990) said that binding of dyes and refractory organic materials that can occur in the environment is very limited, so research is needed on this matter. Refractory organic material in aqueous media is represented by humic substances, such as humic acid and fulvic acid (Sparks, 2003). The term humic compound was first coined by Berzelius in 1830. Humic compound is a high molecular weight macromolecular compound as a result of decomposition of plant organic 
matter and plays an important role in influencing soil properties and chemical species in soils and waters. The chemical structure of humic acid cannot be described as a single form because it is a complex mixture of phenol polyelectrolytes and carbohydrates that vary from one molecule to another (Hayes and Himes, 1986).

Humic compounds are found in coal and peat soils. Peat soil is the result of decay of organic matter in conditions of lack of oxygen. Based on its solubility according to Stevenson (1982) in a variety of acidity solutions, humic compounds can be distinguished from several fractions, namely: (1) Humic acid, a fraction of humic compounds that are not soluble in water with a $\mathrm{pH}$ below 2; (2) Fulvic acid fraction is soluble in water with various conditions, both acids and bases; (3) Humin, is a fraction of humic compounds that are insoluble in all water conditions, both acidic and basic.

Fuch, a German scientist, has proposed the humic acid structure shown in Figure 1. The structure is the result of deduction from various studies on the humic acid structure produced from coal, which consists of aromatic rings containing the $-\mathrm{COOH}$ and $-\mathrm{OH}$ groups (Stevenson, 1994).

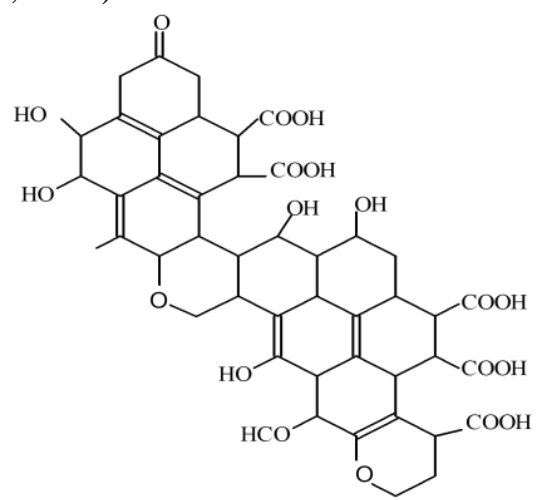

Figure 1. Hypothetical structure of humic acid according to Fuch (Stevenson, 1994).

The main characteristic of humic acid as part of the organic fraction of peat soil is its ability to adsorb organic and inorganic materials. The ability of humic compounds to interact with metal cations is caused by most functional groups of humic acid containing oxygen atoms such as - $\mathrm{COOH}$, -OH phenolics, - $\mathrm{OH}$ enolates, $\mathrm{OH}$ alcoholates and $-\mathrm{C}=\mathrm{O}$. The existence of the $-\mathrm{COOH}$ and $-\mathrm{OH}$ functional groups allows humic acid to be used as an adsorbent (Rahmawati and Sri, 2012).

Dyes are a combination of unsaturated organic substances with chromophores as binding colors with fibers. Unsaturated organic substances are a type of aromatic compounds, namely aromatic hydrocarbons and their derivatives, phenols and their derivatives and nitrogen-containing hydrocarbons (Manurung, 2004).

Naphtol dyes are a type of synthetic dyes commonly used in paper dyes, hair, fabrics and others. Naphtol dyes are included in the type of azo dyes which have two basic components, namely anylic acid and the diazonium salt color generator (Riyanto, 1995).
Dyes based on their structure can be divided into dyes nitroso, nitro, stilbene, diphenyl methane, acridin, kinolin, indigoida, aminokinon, anin and indofenol. If based on the nature of dyes can be divided into acids, bases, disperse, direct and others (Al-Kdasi, 2004). Dyes that are often used in the batik industry include remazol black, golden and yellow, methylene blue, methylene orange, naphtol, indigosol and others.

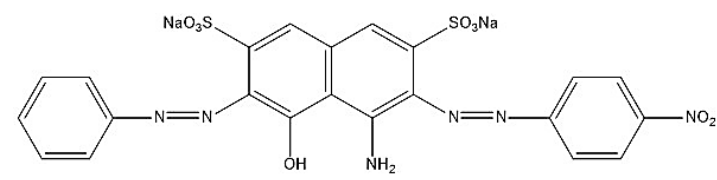

Figure 2. Chemical structure of naphtol dyes.

\section{MATERIALS AND METHODS}

The chemicals used were humic acid, naphtol dyes solution and aquadest. The equipment used included Whatman paper, $\mathrm{pH}$ meter, shaker, and Spectrophotometer UV-VIS.

The method in this research for isolating peat soils refers to method suggested by International Humic Substances Society (IHSS), which was alkaline extraction. Dissolved with $\mathrm{NaOH}$ and precipitated with HCL. Purification by adding 1:1 HCl-HF. Determination of optimum $\mathrm{pH}$ was carried out with variations in $\mathrm{pH} 1$, $2,3,4,5,6,7,8$ and 9 .

\section{Determination of maximum wavelength and manufacture of a standard curve for naphtol AS dye solution}

Making a standard curve is done by making a solution of $100 \mathrm{ppm}$ concentration of naphtol dyes by weighing AS naphtol dyes, blue $\mathrm{b}$ and acoustic diazo salts as much as $0.025 \mathrm{~g}, \quad 0.075 \mathrm{~g}$ and $0.0125 \mathrm{~g}$, respectively. Furthermore, the acoustics are dissolved in distilled water and heated. Hot acoustic solution is used to dissolve AS naphtol, while blue b salt is dissolved in 50 $\mathrm{mL}$ distilled water.

Next, the AS naphtol solution and blue b salt were added to a $250 \mathrm{~mL}$ volumetric flask and added distilled water to the boundary markers and shaken until homogeneous. The $100 \mathrm{ppm}$ parent solution is further diluted to $5,10,15,20,25,30,35,40,45$ and $50 \mathrm{ppm}$.

The maximum wavelength is determined by measuring the solution of US naphtol dyes in the wavelength range of $400-800 \mathrm{~nm}$ using a UV-Vis spectrophotometer. The wavelength that has the greatest absorbance value measured is the maximum wavelength of the naphtol dye. Furthermore, the maximum wavelength is used to measure the solution of naphtol dyes with each concentration of $5,10,15,20,25,30,35$, 40,45 and $50 \mathrm{ppm}$. Then the measurement results are plotted in the relationship curve between concentration and absorbance and include the regression value of the 
curve. The composition of the standard solutions used can be seen in Table 1 .

Table 1. The composition of the volume of making a standard solution of naphtol dyes.

\begin{tabular}{lll}
\hline $\begin{array}{l}\text { Main solution } \\
(\mathbf{1 0 0} \mathbf{p p m}) \text { taken } \\
(\mathbf{m L})\end{array}$ & $\begin{array}{l}\text { Final volume } \\
(\mathbf{m L})\end{array}$ & $\begin{array}{l}\text { Concentration } \\
(\mathbf{p p m})\end{array}$ \\
\hline 2.5 & 50 & 5 \\
5 & 50 & 10 \\
7.5 & 50 & 15 \\
10 & 50 & 20 \\
12.5 & 50 & 25 \\
15 & 50 & 30 \\
17.5 & 50 & 35 \\
20 & 50 & 40 \\
22.5 & 50 & 45 \\
& 50 & 50 \\
\hline
\end{tabular}

\section{Analysis of effect of pH adsorption naphtol dyes}

Humic acid that has been obtained is weighed as much as $10 \mathrm{mg}$ put into a $100 \mathrm{~mL}$ erlenmeyer and $10 \mathrm{~mL}$ of naphtol dye solution is added with the same initial concentration and variations in $\mathrm{pH} 1,2,3,4,5,6,7$ and 8 . Then the mixture is shaken for 2 hours, then filtered with filter paper. Furthermore, it was analyzed by UVVis spectrophotometer with a predetermined naphtol wavelength.

\section{RESULTS AND DISCUSSION}

\section{Determination of naphtol dyes standard curves}

The results of the measurement of the maximum wavelength of napthol dye solution using a UV-Vis spectrophotometer in this study were at 585 $\mathrm{nm}$. Naphtol dyes are substances that do not dissolve in water, so to dissolve it requires an auxiliary substance namely acoustic soda $(\mathrm{NaOH})$. Based on this, the naphtol dyes are called anion dyes. The chromophore groups found in anion dyes include $-\mathrm{N}=\mathrm{N}-, \mathrm{SO}_{3^{-}}, \mathrm{O}-$ and $-\mathrm{OH}$. Chromophores are groups that cause molecules to become colored. The chromophore groups in naphtol dyes have nonbonding free electron pairs, resulting in excitation with low excitation energy. This causes the naphtol dyes to have wavelengths in the visible area.

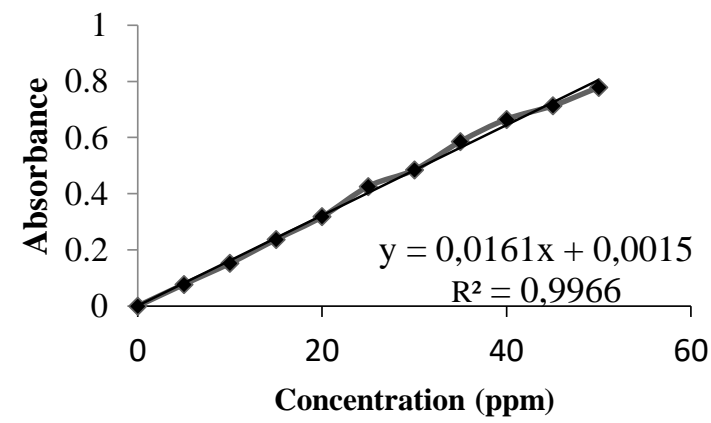

Figure 3. Standard curve for napthol dyes.

\section{Effect of pH adsorption of naphtol dyes}

According to Stum and Morgan (1996) states that changes in $\mathrm{pH}$ can affect changes in the chemical content of adsorbents and adsorbates in solution. Humic acid is also an electrolyte solid that is insoluble at acidic $\mathrm{pH}$ and will dissolve at alkaline $\mathrm{pH}$. This happens because humic acid occurs hydrolyzed reaction. In this study humic acid as an adsorbent and naphtol dyes as an adsorbate.

This research was carried out at a $\mathrm{pH}$ range of $\mathrm{pH} 1$ 9. The results of observations of the influence of acid $\mathrm{pH}$ on the adsorption between humic acid with the following solution of naphtol dyes:

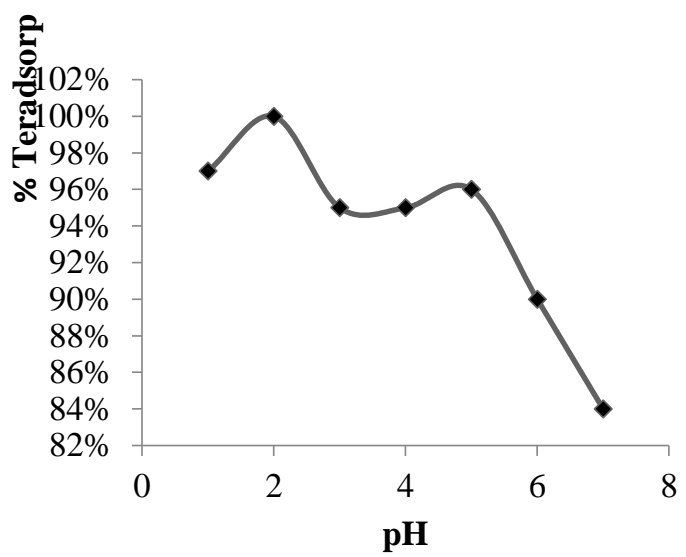

Figure 4. The curve of the influence of $\mathrm{pH} 1-7$ on the $\%$ concentration of adsorbed naphtol dyes solution by humic acid

The results of this study are shown in Figure 4 that the percentage of concentration will decrease with increasing $\mathrm{pH}$ of naphtol dyes. This means that the higher the $\mathrm{pH}$ of the naphtol dyes that are adsorbed the less, so that the more acidic $\mathrm{pH}$ of the naphtol dyes that are adsorbed more and more. According to Delgoda et al., (2004) and Santoso et al., (2008) under acidic conditions, humic acid was protonated (receiving $\mathrm{H}^{+}$) so that the $-\mathrm{COOH}$ group became $-\mathrm{COOH}_{2}{ }^{+}$and $-\mathrm{OH}$ became $-\mathrm{OH}_{2}{ }^{+}$. Then the interaction that occurred in this research is through electrostatic interactions where the $\mathrm{COOH}_{2}{ }^{+}$and $-\mathrm{OH}_{2}{ }^{+}$groups of humic acid will bind electrons from naphtol dyes. This study can be concluded that the optimum $\mathrm{pH}$ of adsorption of naphtol dyes by humic acid is at $\mathrm{pH} 2$. The reaction in the humic acid functional group due to changes in acid $\mathrm{pH}$ can be written the following equation.

$$
\begin{aligned}
& -\mathrm{COOH}+\mathrm{H}^{+} \underset{-}{\rightleftarrows}-\mathrm{COOH}_{2}{ }^{+} \\
& -\mathrm{OH}+\mathrm{H}^{+} \rightleftarrows-\mathrm{OH}_{2}
\end{aligned}
$$

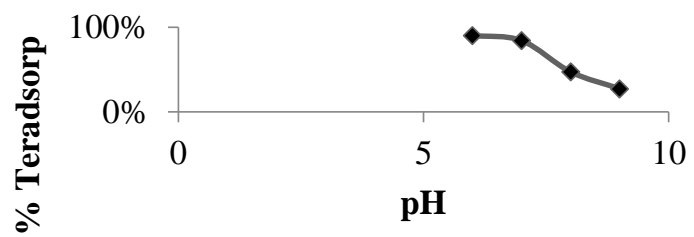

Figure 5. Curve of the effect of $\mathrm{pH}$ 6-9 on the $\%$ concentration of adsorbed naphtol dyes solution by humic acid. 
The effect of $\mathrm{pH}$ on the adsorption of humic acid with naphtol dyes is shown in Figure 5 that the higher the $\mathrm{pH}$ of the naphtol dyes solution, the smaller the percentage of the concentration of the naphtol dyestuff solution adsorbed. This is caused by humic acid dissolving under alkaline $\mathrm{pH}$ conditions, so that naphtol dyes are not completely absorbed by humic acid. The interaction between humic acid and naphtol dyes is influenced by the presence of hydrogen bonds. In addition, other factors that can affect interactions at basic $\mathrm{pH}$ are $\mathrm{pH} 8$ and 9 humic acid deprotonation process (releasing $\mathrm{H}^{+}$), so that the group $-\mathrm{COOH}$ becomes $\mathrm{COO}$ - and -OH becomes O-.

The interaction of naphtol dyes with humic acid in hydrogen bonds can be illustrated in Figure 6 and electrostatic bonds are illustrated in Figure 7.

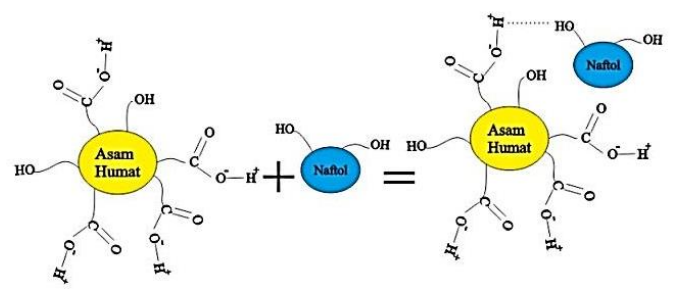

Figure 6. Illustration of hydrogen bonds of humic acid and napthol dyes.

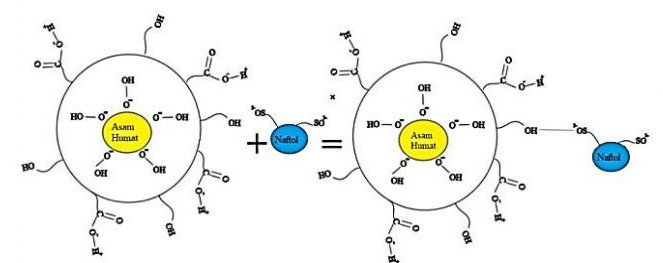

Figure 7. Illustration of electrostatic bonds of humic acid and naphtol dyes.

\section{CONCLUSIONS}

Based on research, it can be concluded that humic acid from Kalimantan peat soil isolation can adsorb optimum naphtol dye solution at $\mathrm{pH} 2$. Because under acidic conditions, humic acid was protonated (receiving $\mathrm{H}^{+}$) so that the $-\mathrm{COOH}$ group became $-\mathrm{COOH}_{2}{ }^{+}$and $-\mathrm{OH}$ became $-\mathrm{OH}_{2}{ }^{+}$. In addition, other factors that can affect interactions at basic $\mathrm{pH}$ are $\mathrm{pH} 8$ and 9 humic acid deprotonation process (releasing $\mathrm{H}^{+}$), so that the group $\mathrm{COOH}$ becomes $-\mathrm{COO}^{-}$and $-\mathrm{OH}$ becomes $\mathrm{O}^{-}$.

\section{ACKNOWLEDGEMENTS}

Thanks to the supervisor who always directs and motivates the writer.

\section{REFERENCES}

Al-Kdasi A, Idris A, Saed K, Guan CT. 2004. Treatment of Textile Wastewater by Advanced Oxidation Processes. Global Nest the Int J 6: 222-230.

Banerjee P, Dasgupta S, De S. 2007. Removal of Dye from Aqueous Solution Using a Combination of Advanced Oxidation Process and Nanofiltration. Journal of Hazardous Materials 140(1-2): 95-103.

Hayes MB, Himes FL. 1986. Nature and Properties of HumusMineral Complexes in: Interaction of Soil Mineral with Natural Organics and Microbes. Soil Science Society of America (SSSA) Special Publication, USA.

Laksono EW. 2012. Kajian Penggunaan Adsorben sebagai Alternatif Pengolahan Limbah Zat Pewarna Tekstil. [Thesis]. Universitas Negeri Yogyakarta, Yogyakarta. [Indonesian]

Manurung R, R Hasibuan, Irvan. 2004. Perombakan zat warna azo reaktif secara anaerob-aerob. [Karya tulis]. Fakultas Teknik Universitas Sumatera Utara, Sumatera Utara. [Indonesian]

Prandini MN. 2018. Adsorpsi Zat Warna Naphtol Menggunakan Adsorben Asam Humat Hasil Isolasi Tanah Gambut Kalimantan. [Thesis] Universitas Islam Negeri Sunan Kalijaga, Yogyakarta. [Indonesian]

Putra, Dhafid Etana, Fitri Puji A, and Edi S. 2014. Studi Penurunan Kadar Logam (Fe) pada Limbah Batik dengan Sistem Purifikasi Menggunakan Adsorben Nanopartikel Magnetit $\left(\mathrm{Fe}_{3} \mathrm{O}_{4}\right)$. Prosiding Pertemuan Ilmiah XXVIII HFI Jateng dan DIY. Yogyakarta, 26 April 2014. [Indonesian]

Rachmawati S, Joko T, Astorina N. 2016. Perbedaan Variasi Penambahan Media Adsorpsi Kontak Aerasi Sistem Nampan Bersusun (Tray Aerator) terhadap Kadar Besi (Fe) Air Sumur Gali Di Desa Jatihadi Kecamatan Sumber Kabupaten Rembang. Jurnal Universitas Diponegoro. Semarang. [Indonesian]

Rahmawati A, Sri JS. 2012. Studi Adsorpsi Logam Pb(II) dan Cd(II) pada Asam Humat dalam Medium Air. Alchemy 2(1): 46-57.

Rahmawati, Atik. 2011. Isolasi dan Karakterisasi Asam Humat dari Tanah Gambut. Jurnal Phenomeon 2(1).

Rahmayanti M, Yunita E, Prandini MN. 2019. Isolasi Asam Humat dari Tanah Gambut Sumatera dan Kalimantan dan Analisis Kandungan Gugus Fungsionalnya. Integrated Lab Journal 7(2).

Rahmayanti, Maya. 2016. Imobilisasi Asam Salisilat, Asam Galat dan Asam Humat pada Magnetit serta Aplikasinya untuk Adsorpsi [ $\mathrm{AuCl}_{4}$ ]. [Dissertation]. Universitas Gadjah Mada, Yogyakarta.

Riyanto, Didik. 1995. Press Batik: Batik Tulis - Batik Cap Batik Printing. CV Aneka, Solo.

Santoso UT, Irawati U, Umaningrum D, Nurmasari R. 2008. Imobilisasi Asam Humat pada Kitosan menggunakan Metode Pengikatan-Silang Terproteksi dan Aplikasinya sebagai Adsorben $\mathrm{Pb}$ (II) dan Cd (II). Prosiding Seminar Nasional Kimia, Yogyakarta. [Indoensian]

Setyaningsih H. 2007. Pengolahan Limbah Batik dengan Proses Kimia dan Adsorpsi Karbon Aktif. [Thesis]. Program Pasca Sarjana UI, Jakarta. [Indonesian]

Spark KM, Wells JD, Johnson BB. 2003. The Interaction of Humic Acid with Heavy Metals. Aus J Soil Sci, 59: 505-516.

Stevenson, FJ. 1994. Humus chemistry. Genesis, Composition and Reactions: II Ed. John \& Sons, JNC, New York. 
Stevenson, FJ.1982. Humus Chemistry: Genesis, Composition, Reactions. John Wiley \& Sons, New York.

Stum W, Morgan. 1981. Aquatic Chemistry. John Wiley \& Sons, New York.
Sunu, Pramudya. 2001. Melindungi Lingkungan dengan Menerapkan ISO 14001. Gramedia, Jakarta. 
THIS PAGE INTENTIONALLY LEFT BLANK 